\section{Salmonella Recovery from Tomato Fruit Surfaces as Affected by Ethylene}

\author{
Michael J. Mahovic ${ }^{1,3}$, Keith R. Schneider ${ }^{1}$, Kim Cordasco $^{2}$, and \\ Jeffrey K. Brecht ${ }^{2}$
}

ADDITIONAL INDEX WORDs. ripening room, food safety, bacterial survival, bacterial proliferation, Solanum lycopersicum

\begin{abstract}
Summary. The effect of ethylene on the survival of Salmonella cells residing on unwounded surfaces of tomato (Solanum lycopersicum) fruit was investigated in this study. Inoculated fruit were stored in flow-through chambers that were adjusted to maintain an environment simulating a tomato ripening room. Fruit were held at $20{ }^{\circ} \mathrm{C}$ and $\geq 95 \%$ relative humidity after surface inoculation with the low virulence and rifamycin-resistant pathogen $S$. enterica ssp. enterica serovar Typhimurium strain LT2 ( $S$. Typhimurium). Tomato fruit were treated either with a continuous flow (rate, $\approx 200 \mathrm{~mL} \cdot \mathrm{min}^{-1}$ ) of air or with $\geq 150 \mu \mathrm{L} \cdot \mathrm{L}^{-1}$ ethylene in air. Bacterial recovery at $0,24,48$, and $72 \mathrm{~h}$ after initiation of treatment showed that total populations of the $S$. Typhimurium cells declined in both the air and ethylene treatments during the first 24 to $48 \mathrm{~h}$ of storage, then increased to near initial levels by $72 \mathrm{~h}$, similar to decline and recovery reported by other researchers in nonethylene treatment trials. These results suggest that although Salmonella can survive on the surfaces of tomato fruit in typical ripening rooms, proliferation of Salmonella is neither promoted nor inhibited by ethylene exposure.
\end{abstract}

$\mathrm{R}$ ecently, the consumption of raw tomatoes has been indicated in several outbreaks of enteric disease incited by serovars of the bacteria Salmonella enterica ssp. enterica (Cummings et al., 2001; Hedberg et al., 1999; Toth et al., 2002; Wood et al., 1991). In most cases, diced or otherwise foodserviceprepared tomatoes were responsible. Contamination of the fruit has been traced back to packinghouses in some cases, but the specifics of contamination and the reliability of these "tracebacks" have not been determined (Centers for Disease Control and Prevention, 2005).

In packinghouses, after being graded and packed, mature green tomatoes are typically treated with the gaseous plant growth regulator ethylene $\left(\mathrm{C}_{2} \mathrm{H}_{4}\right)$ for a number of days at 20 to $21{ }^{\circ} \mathrm{C}$ in ripening rooms. It has been recommended that this treatment need last no more than $3 \mathrm{~d}$ (Sargent et al., 2005), but as many as $9 \mathrm{~d}$ of treatment have been reported by industry professionals (authors' pers. obs.), depending on the maturity of the fruit at harvest. Certain fungi have been observed to react to

${ }^{1}$ Department of Food Science and Human Nutrition, University of Florida, Gainesville, FL 32611

${ }^{2}$ Department of Horticultural Sciences, University of Florida, Gainesville, FL 32611

${ }^{3}$ Corresponding author. E-mail: mmahovic@ifas.ufl.edu the presence of $\mathrm{C}_{2} \mathrm{H}_{4}$ with stimulated growth or increased germ tube elongation (El-Kazzaz et al., 1983). Bacterial response to $\mathrm{C}_{2} \mathrm{H}_{4}$, however, has not been characterized. Specifically, a response by Salmonella to elevated $\mathrm{C}_{2} \mathrm{H}_{4}$ concentrations has not been reported. If cells of Salmonella are responsive to $\mathrm{C}_{2} \mathrm{H}_{4}$, fruit ripening treatments may lead to greater survival or proliferation of any Salmonella present, potentially increasing the likelihood of disease outbreak in consumers. Previous work suggests that Salmonella cells in ripening room conditions $\left[\approx 20{ }^{\circ} \mathrm{C}\right.$ and $85 \%$ to $90 \%$ or higher relative humidity $(\mathrm{RH})]$ can survive and multiply for at least $7 \mathrm{~d}$ (Zhuang et al., 1995), possibly surviving for more than $28 \mathrm{~d}$ (Allen, 2003). A 30\% reduction in $\mathrm{RH}$ values (from $90 \%$ to $60 \%$ ) at $20{ }^{\circ} \mathrm{C}$ reduced survival (Allen, 2003; Guo et al., 2002). However, the presence and any effects of $\mathrm{C}_{2} \mathrm{H}_{4}$ in those experiments were not explored. The research reported in this paper was performed to determine the effect, if any, of $\mathrm{C}_{2} \mathrm{H}_{4}$ in simulated ripening room conditions on the survival of Salmonella on the surfaces of whole tomato fruit.

\section{Materials and methods}

Tomato fruit were acquired from Florida growers (cultivars either unknown or Florida-47) and stored in the laboratory at room temperature $\left(22^{\circ} \mathrm{C}\right)$ to expedite ripening or in a reach-in chamber at $12.5^{\circ} \mathrm{C}$ to stall ripening, for up to $5 \mathrm{~d}$ before use. Fruit were randomized by ripeness stage according to a commercial ripeness guide (United Fresh Fruit and Vegetable Association and U.S. Department of Agriculture, 1975), ranging from breaker to red, as they were grouped for each trial. Fruit were collected before being run along grading lines and so were unwashed and did not have any coatings (wax or mineral oils, etc.) applied.

A stock culture of the lowvirulence pathogen S. enterica ssp. enterica serovar Typhimurium, strain LT2 (ATCC 15277), that was adapted for resistance to rifamycin (Rif ${ }^{+}$ at $200 \mu \mathrm{g} \cdot \mathrm{L}^{-1}$ ) was used as the test inoculum. Cells were recovered from Protect Bacterial Preserver Beads (Scientific Device Laboratories, Des Plaines, Ill.) by incubation in tryptic soy broth (TSB). After overnight growth $(12 \mathrm{~h})$ on a rotary shaker $(30 \mathrm{rpm})$ in an incubator $\left(40^{\circ} \mathrm{C}\right)$, cells were reinoculated to fresh TSB and allowed to incubate overnight again under the same conditions. This was done a total of three times. After the third generation, cells were streaked with tryptic soy agar (TSA) with rifamycin SV sodium salt (Sigma Chemical Co., St. Louis, Mo.) at 80 $\mu \mathrm{g} \cdot \mathrm{L}^{-1}$ and stored overnight at $40{ }^{\circ} \mathrm{C}$. Antibiotic concentrations were gradually increased on subsequent generations in this manner until surviving colonies were present on agar plates with $200 \mu \mathrm{g} \cdot \mathrm{L}^{-1}$ rifamycin. Cells were

\begin{tabular}{llll}
\hline $\begin{array}{l}\text { Units } \\
\begin{array}{l}\text { To convert U.S. to SI, } \\
\text { multiply by }\end{array}\end{array}$ & U.S. unit & SI unit & $\begin{array}{l}\text { To convert SI to U.S., } \\
\text { multiply by }\end{array}$ \\
\hline 29,574 & $\mathrm{fl} \mathrm{oz}$ & $\mu \mathrm{L}$ & $3.3814 \times 10^{-5}$ \\
29.5735 & $\mathrm{fl} \mathrm{oz}$ & $\mathrm{mL}$ & 0.0338 \\
0.0283 & $\mathrm{ft}^{3}$ & $\mathrm{~m}^{3}$ & 35.3147 \\
0.4536 & $\mathrm{lb}$ & $\mathrm{kg}$ & 2.2046 \\
1 & $\mathrm{ppb}$ & $\mu \mathrm{g} \cdot \mathrm{L}^{-1}$ & 1 \\
1 & $\mathrm{ppm}$ & $\mu \mathrm{L} \cdot \mathrm{L}^{-1}$ & 1 \\
$\left({ }^{\circ} \mathrm{F}-32\right) \div 1.8$ & ${ }^{\circ} \mathrm{F}$ & ${ }^{\circ} \mathrm{C}$ & $\left(1.8 \times{ }^{\circ} \mathrm{C}\right)+32$
\end{tabular}


then maintained on $200 \mu \mathrm{g} \cdot \mathrm{L}^{-1} \mathrm{Rif}^{+}$ TSA plates at room temperature.

For inoculation, a sample of the prepared rifamycin-resistant cells was transferred to a $200-\mu \mathrm{g} \cdot \mathrm{L}^{-1} \mathrm{Rif}^{+} \mathrm{TSB}$ tube and incubated overnight at $40{ }^{\circ} \mathrm{C}$ on a rotary shaker. The suspension was spun down in a centrifuge (IEC Centra MP4R; International Equipment Co., Needham Heights, Mass.) at $450 g_{\mathrm{n}}$ for $10 \mathrm{~min}$. The supernatant was decanted and the pellet resuspended in $10 \mathrm{~mL}$ phosphate buffered saline, then centrifuged again. Cells were washed using this procedure three times before testing. A sample of the stock inoculum was serially diluted and plated using pour-plate technique and $100 \mu \mathrm{g} \cdot \mathrm{L}^{-1} \mathrm{Rif}^{+}$TSA for determination of stock concentration. Just before initiation of the trials, each tomato was spot-inoculated 10 times around the blossom scar, across replicates, with $10 \mu \mathrm{L} \quad 7.69 \log _{10}$ $\mathrm{cfu} \cdot \mathrm{mL}^{-1}$ stock inoculum in each spot $\left(100 \mu \mathrm{L}\right.$ per fruit, or total $\approx 6 \log _{10}$ cfu/fruit). Fruit were allowed to air dry for about $\mathrm{l} \mathrm{h}$ before being placed into a treatment chamber, making sure inoculation points did not contact adjacent fruit or the chamber wall.

$\mathrm{C}_{2} \mathrm{H}_{4}$ treatment chambers $(10-\mathrm{L}$ glass jars) contained a similar ratio of fruit to volume at the same temperature and $\mathrm{RH}$ as would be found in a commercial tomato ripening room that was operated using recommended conditions (Sargent et al., 2005). A standard tomato ripening room has space for two truckloads of packed and palletized tomato fruit. A single truckload consists of 20 pallets, with each pallet made up of $10025-\mathrm{lb}$ boxes of tomatoes. Therefore, a standard two-truckload ripening room containing 40 pallets total includes about $100,000 \mathrm{lb}$ of fruit. A standard ripening room volume is $9980 \mathrm{ft}^{3}$ (Sherman and Talbot, 1986), so when filled with 100,000 $\mathrm{lb}$ fruit, there are $\approx 10 \mathrm{lb}$ fruit $/ \mathrm{ft}^{3}$. The volume of the glass jars used as treatment chambers was $10.0 \mathrm{~L}(0.35$ $\left.\mathrm{ft}^{3}\right)$; therefore, 10 fruit $[\approx 1.6 \mathrm{~kg}$ $(3.53 \mathrm{lb})]$ were placed into each jar. In the third trial (only), five fruit were used for each chamber because of limited resources.

Treatment of tomato fruit consisted of four predetermined time intervals of continuous exposure either to air or to $\mathrm{C}_{2} \mathrm{H}_{4}$ at $\geq 150 \mu \mathrm{L} \cdot \mathrm{L}^{-1}$, the recommended dosage of $\mathrm{C}_{2} \mathrm{H}_{4}$ in a tomato ripening room (Sargent et al., 2005). Each treatment chamber was connected to a flow-through gas system in which $\mathrm{C}_{2} \mathrm{H}_{4}$ and air from pressurized gas cylinders were mixed at constant pressure via a gas mixing board equipped with needle valve flow meters. Treatment levels were quickly established at the onset of treatment by injecting a calculated volume of pure $\mathrm{C}_{2} \mathrm{H}_{4}$ into the container. A gas chromatograph (model 540; Tracor Instruments, Austin, Texas) with a photoionization detector and 3 - $\mathrm{ft}$ stainless steel column packed with alumina F-1, 80/100 size mesh was used to quantify $\mathrm{C}_{2} \mathrm{H}_{4}$.

The total flow rate to each jar was $\approx 200 \mathrm{~mL} \cdot \mathrm{min}^{-1}$, which exceeded the recommended minimum air exchange in a tomato ripening room of at least one room volume every $6 \mathrm{~h}$ (Sargent et al., 2005). To maintain the recommended $\mathrm{RH}$ of $\geq 85 \%$, deionized water was misted into each chamber before the addition of fruit. Also, during treatment, the gas mixtures were bubbled through deionized water using submerged aquarium aerator stones in separate, in-line, sealed glass jars $(500 \mathrm{~mL})$. Treatment jars were exhausted to outside the storage facility via a PVC exhaust system that pulled a slight vacuum, using the Venturi effect. The entire system was held in a walk-in incubator with a regulated temperature $\left(20^{\circ} \mathrm{C}\right)$. To verify the temperature and $\mathrm{RH}$, a digital environmental recorder (WatchDog model 250; Spectrum Technologies, Inc., Plainfield, Ill.) was placed in each of the 72-h treatment chambers (with and without $\mathrm{C}_{2} \mathrm{H}_{4}$ ) for all trials.

In each trial, six treatment chambers of tomato fruit were used for two treatments (with and without $\mathrm{C}_{2} \mathrm{H}_{4}$ ) and three time periods each $(24,48$, and $72 \mathrm{~h}$ ). A fourth group of fruit was inoculated at the same time as the other treatments $\left(\mathrm{T}_{0}\right)$, but was not stored and was included as an untreated control; fruit from this treatment were treated to recover surface inoculated $S$. Typhimurium immediately after the storage trials were initiated. After each predetermined $\mathrm{C}_{2} \mathrm{H}_{4}$ exposure period had elapsed (including $\mathrm{T}_{0}$ controls), fruit were removed from one $\mathrm{C}_{2} \mathrm{H}_{4}$-treated and one untreated chamber and placed on trays. Fruit were immedi- ately treated to recover any Rifresistant $S$. Typhimurium present on the surface by individually placing fruit into a sealed stomacher bag with $100 \pm 5.0 \mathrm{~mL}$ sterile tap water $(\mathrm{sec}-$ ond trial) or phosphate buffered saline (all other trials) followed by manual rubbing and shaking for 1 min (Burnett and Beuchat, 2001). After manual agitation, the fruit were removed from the bag and discarded, saving the liquid contents and any liberated, suspended cells. Recovery treatment alternated individually between the "with" and the "without" $\mathrm{C}_{2} \mathrm{H}_{4}$ samples at each sampling time, until recovery treatment had been conducted for all fruit.

After all fruit were treated for bacterial cell recovery and discarded, the liquid samples were each serially diluted three times, at a $1: 10$ ratio each, in fresh volumes of the same type of liquid used during the recovery suspension. The total dilutions were $10^{-2}$ for the initial $100-\mathrm{mL}$ recovery, $10^{-3}$ for the first $1: 10$ dilution, $10^{-4}$ for the second and $10^{-5}$ for the third. A 1-mL sample from each dilution in the series was pour-plated to a $100 \mu \mathrm{g} \cdot \mathrm{L}^{-1} \mathrm{Rif}^{+}$TSA Petri dish. Plates were labeled, allowed to solidify, and were then incubated upside down for $48 \mathrm{~h}$ in a $37^{\circ} \mathrm{C}$ chamber. Plates were stored in loosely sealed 7.0-L anaerobic gas chambers (AnaeroPack System; Mitsubishi Gas Chemical Co., Tokyo, Japan) to avoid desiccation. After incubation, plates were counted for total colony forming units of Rif-resistant cells recovered. Plates with 30 to $300 \mathrm{cfu} /$ plate were back-calculated to total cells per fruit, accounting for all dilutions. Data from three trials were averaged and SDs were calculated to determine 95\% confidence intervals.

\section{Results and discussion}

Recorded $\mathrm{C}_{2} \mathrm{H}_{4}$ levels were maintained at or above $150 \mu \mathrm{L} \cdot \mathrm{L}^{-1}$ (the recommended ripening room dose) throughout the experiments. As verified by the digital environmental recorders, the temperature was maintained at $20 \pm 0.6^{\circ} \mathrm{C}$ throughout the study and the $\mathrm{RH}$ levels in all chambers were $\geq 90 \%$ within $2 \mathrm{~h}$, reaching and maintaining more than $99 \%$ in less than $12 \mathrm{~h}$. Infusing the treatment chambers with misted water before the addition of fruit ensured the $\mathrm{RH}$ was high $(>80 \%)$ at 


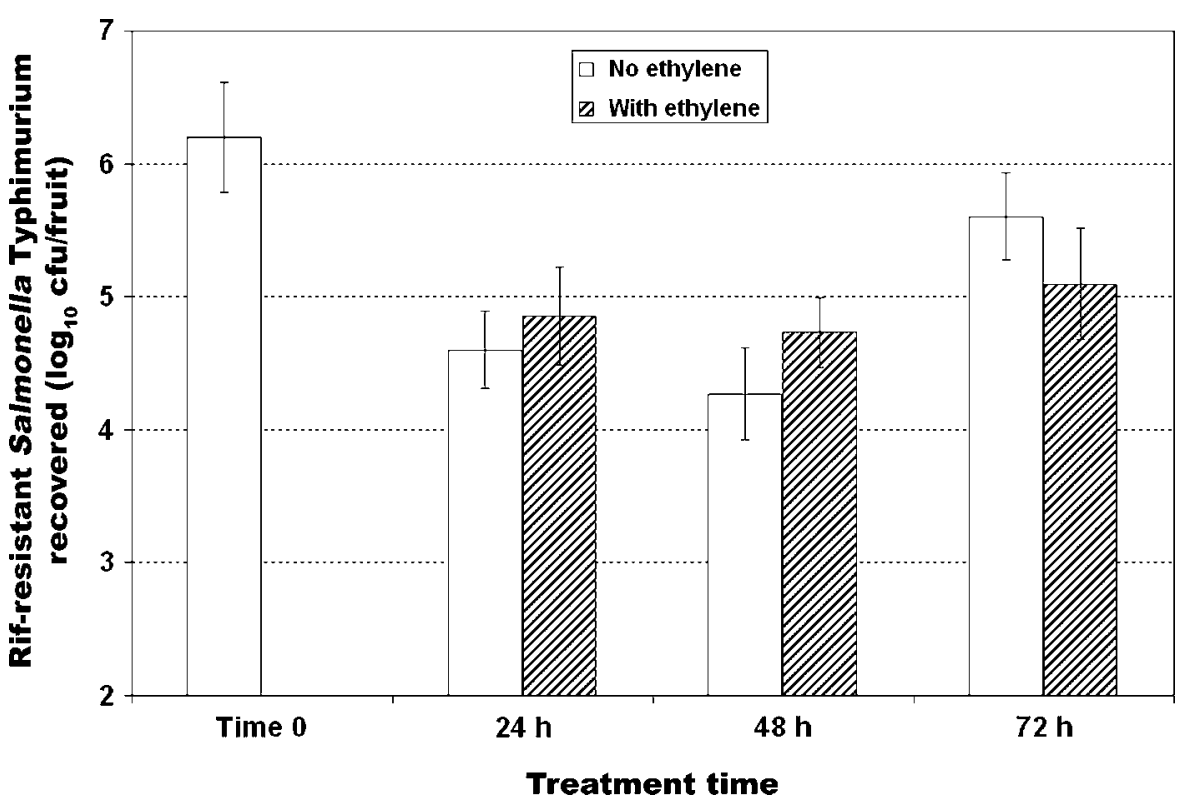

Fig. 1. Recovery of Rif-resistant Salmonella enterica ssp. enterica serovar Typhimurium strain LT2 ( $S$. Typhimurium) from intact tomato fruit surfaces, after flow-through treatment with air or $\geq 150 \mu \mathrm{L} \cdot \mathrm{L}^{-1}(\mathrm{ppm})$ ethylene over four time periods $(P=\mathbf{0 . 0 5})$.

the initiation of each trial. Use of aquarium aerator stones in the humidifier chambers produced fine bubbles of incoming gas, thus maximizing the total surface area of the gas that was in contact with water and the amount of water vapor carried into the treatment jars. This helped maintain $\geq 97 \% \mathrm{RH}$, eliminating loss of bacteria as a result of desiccation (Guo et al., 2002), as was observed in an initial trial without the in-line humidification chambers, when $\mathrm{RH}$ remained less than $75 \%$ (data not shown).

Inoculum was present and recoverable from all fruit. Data are the compilation results of three trials (Fig. 1) at each treatment time. Error bars represent the 95\% confidence interval of recoverable and countable (30-300 cfu/plate) cells. Inoculum recovered from control fruit, immediately after drying and before any $\mathrm{C}_{2} \mathrm{H}_{4}$ treatment, was $6.2 \log _{10}(\mathrm{sD}=$ 0.97 ) after inoculation with $100 \mu \mathrm{L}$ from a broth of $7.69 \mathrm{cfu} \cdot \mathrm{mL}^{-1}$ $S$. Typhimurium $(\mathrm{SD}=0.18)$. After $24 \mathrm{~h}, \approx 4.7 \log _{10}$ bacteria were recovered from both treated and untreated fruit, which is a $1.5 \mathrm{log}$ cycle reduction in bacterial populations compared with positive control fruit at $\mathrm{T}_{0}$. Bacterial populations recovered after $48 \mathrm{~h}$, with or without $\mathrm{C}_{2} \mathrm{H}_{4}$ treatment, were not significantly dif- ferent $(P=0.05)$ from those recovered after $24 \mathrm{~h}$. After $72 \mathrm{~h}$, bacteria that were in $\mathrm{C}_{2} \mathrm{H}_{4}$ treatments increased to $5.1 \log _{10}$, which was not significantly greater than recovery levels after 24 or $48 \mathrm{~h}$, nor was it different from fruit not treated with $\mathrm{C}_{2} \mathrm{H}_{4}$ at $72 \mathrm{~h}$. Conversely, fruit treated with air only had an unexpected and significant increase in recoverable cells at $72 \mathrm{~h}$. Similar variations have been previously reported (Allen, 2003), but were not significant in the overall trend of decreasing recovery. Because recovery was not different from $\mathrm{C}_{2} \mathrm{H}_{4}$-treated fruit at this time, although the cause of this growth was unknown, it can be surmised that it was not the $\mathrm{C}_{2} \mathrm{H}_{4}$ treatment.

At each sampling time (Fig. 1), lack of significant differences between treatments $(P=0.05)$ suggests that, at the concentration used in tomato ripening rooms, $\mathrm{C}_{2} \mathrm{H}_{4}$ does not have an effect upon growth rates of $S$. Typhimurium cells. Although higher $\mathrm{C}_{2} \mathrm{H}_{4}$ concentrations than those used in this research may have an effect on bacterial recovery, this possibility was not explored. Higher $\mathrm{C}_{2} \mathrm{H}_{4}$ concentrations are unlikely to be encountered, considering that concentrations used here equal or exceed current recommendations for a tomato ripening room (Sargent et al., 2005). Because it has previously been shown that Salmonella spp. cells can survive on intact tomato fruit surfaces for at least $28 \mathrm{~d}$ at the recommended ripening conditions of $20{ }^{\circ} \mathrm{C}$ and $90 \% \mathrm{RH}$ (Allen, 2003), it may be of interest to determine whether and how $\mathrm{C}_{2} \mathrm{H}_{4}$ treatment affects recovery rates of surface-inoculated tomatoes after extended exposure to $\mathrm{C}_{2} \mathrm{H}_{4}$ (up to or beyond $7 \mathrm{~d}$ ), or whether $\mathrm{C}_{2} \mathrm{H}_{4}$ treatment affects subsequent Salmonella spp. survival during extended storage times of up to $28 \mathrm{~d}$, after treatment has been ended.

\section{Literature cited}

Allen, R.L. 2003. A recovery study of Salmonella spp. from the surfaces of tomatoes and packing line materials. Dept. of Food Science and Human Nutrition, Univ. of Florida, Gainesville, Fla., M.S. thesis.

Burnett, A.B. and L.R. Beuchat. 2001. Comparison of sample preparation methods for recovering Salmonella from raw fruits, vegetables, and herbs. J. Food Prot. 10:1459-1465.

Centers for Disease Control and Prevention. 2005. Outbreaks of Salmonella infections associated with eating Roma tomatoes-United States and Canada, 2004. MMWR Morbid. Mortal. Wkly. Rpt. 13:325-328.

Cummings, K., E. Barrett, J.C. MohleBoetani, J.T. Brooks, J. Farrar, T. Hunt, A. Fiore, K. Komatsu, S.B. Werner, and L. Slutsker. 2001. A multistate outbreak of Salmonella enterica serotype Baildon associated with domestic raw tomatoes. Emerg. Infect. Dis. 6:1046-1048.

El-Kazzaz, M.K., N.F. Sommer, and A.A. Kader. 1983. Ethylene effects on in vitro and in vivo growth of certain postharvest fruit-infecting fungi. Phytopathology 7:998-1001.

Guo, X., J.R. Chen, R.E. Brackett, and L.R. Beuchat. 2002. Survival of Salmonella on tomatoes stored at high relative humidity, in soil, and on tomatoes in contact with soil. J. Food Prot. 2:274-279.

Hedberg, C.W., F.J. Angulo, K.E. White, C.W. Langkop, W.L. Schell, M.G. Stobierski, A. Schuchat, J.M. Besser, S. Dietrich, L. Helsel, P.M. Griffin, J.W. Mcfarland, and M.T. Osterholm. 1999. Outbreaks of salmonellosis associated with eating uncooked tomatoes: Implications for public health. Epidemiol. Infect. 3:385-393.

Sargent, S.A., J.K. Brecht, and T. Olczyk. 2005. Handling Florida vegetables series: 
Round and Roma tomato types. 20 June 2006. <http://edis.ifas.ufl.edu/VH079>

Sherman, M. and M.T. Talbot. 1986. Vegetable crops fact sheet (VC-35): Simple modifications that improve air distribution within ripening rooms. Coop. Ext. Serv., Univ. Florida, Inst. Food Agr. Sci., Gainesville, Fla.

Toth, B., D. Bodager, R.M. Hammond, S. Stenzel, J.K. Adams, T. Kass-Hout, R.M. Hoekstra, P.S. Mead, and P. Srikantiah. 2002. Outbreak of Salmonella serotype
Javiana infections-Orlando, Florida, June 2002. MMWR Morbid. Mortal. Wkly. Rpt. 31:683-684.

United Fresh Fruit and Vegetable Association and U.S. Department of Agriculture. 1975. Color classification requirements in tomatoes: U.S. standards for grades of fresh tomatoes. John Henry Co., Lansing, Mich.

Wood, R.C., C. Hedberg, and K. White. 1991. A multistate outbreak of Salmonella Javiana infections associated with raw tomatoes. Center for Disease Control Epidemic Intelligence Serv. 40th annual conf. (abstr.).

Zhuang, R.Y., L.R. Beuchat, and F.J. Angulo. 1995. Fate of Salmonella montevideo on and in raw tomatoes as affected by temperature and treatment with chlorine. Appl. Environ. Microbiol. 6:21272131. 